\title{
STATUS HAK ATAS TANAH PASCA BENCANA LIKUIFAKSI DAN RENCANA TATA RUANG WILAYAH DI KOTA PALU
}

\author{
Nurhilma Lestari \\ Lembaga Pengkajian Hukum Dan HAM Kota Malang \\ Jl. Kumis Kucing 42A Malang \\ Email: nurhilmalestari@gmail.com
}

\begin{abstract}
Abstrak
Adapun hasil penelitian dan pembahasan sebagai berikut: 1). Masyarakat di kawasan yang terdampak likuifaksi (kelurahan petobo, kecamatan palu selatan, kota palu, provinsi sulawesi tengah) sesuai dengan pergub nomor 10 tahun 2019, bahwa masyarakat tidak dapat menuntut lagi tanahnya di kawasan terdampak likuifaksi. Sebab, sangat jelas dalam pergub nomor 10 tahun 2019 bahwa kawasan terdampak likuifaksi di kelurahan petobo termasuk dalam zona merah, yang dalam hal ini dengan dipindahkan masyarakat korban bencana likuifaksi ke lokasi lebih aman (relokasi). Maka dengan adanya relokasi tersebut, masyarakat tidak lagi dapat menuntut hak atas tanahnya di kawasan terdampak likuifaksi,2). Berdasarkan pergub nomor 10 tahun 2019,mengatur mengenai penataan ruang wilayah perlunya perubahan pemanfaatan ruang di beberapa lokasi terdampak bencana masif, maka menjadi penting penyusunan arahan pemanfaatan ruang baru yang dapat diterima oleh masyarakat. Disamping itu, di daerah-daerah yang tidak terdampak bencana, maka arahan pemanfaatan ruang lama akan mengalami perubahan minimal, atau bahkan tidak berubah sama sekali. Kesimpulan yang bisa diambil dari penelitian ini adalah Bahwa masyarakat di kawasan terdampak (Kelurahan Petobo, Kecamatan Palu Selatan, Kota Palu, Provinsi Sulawesi Tengah) sesuai dengan Pergub Nomor 10 Tahun 2019, bahwa masyarkat tidak dapat lagi menuntut tanahnya di kawasan terdampak. Sebab, sangat jelas didalam pergub Nomor 10 Tahun 2019 bahwa kawasan terdampak (Keluarahan Petobo) termasuk dalam Zona Merah, yang dalam hal ini dengan dipindahkannya masyarakat korban bencana dikawasan terdampak ke lokasi yang lebih aman (relokasi). Maka, dengan adanya relokasi tersebut, masyarakat tidak lagi dapat menuntut hak atas tanahnya dikawasan terdampak, dan Pemerintah Daerah Provinsi Sulawesi Tengah telah mengeluarkan Peraturan Gubernur Sulawesi Tengah No. 10 Tahun 2019 Tentang Rencana Rehabilitasi dan Relokasi Pascabencana, yang mengatur pelaksanaan pembangunan rumah untuk relokasi korban likuifaksi yang memiliki hak atas tanah dan bangunan secara sah menurut hukum. Pembangunan tempat tinggal untuk relokasi disini prinsipnya adalah pemerataan dan adil antara luas tanah dan fisik rumah adalah sama
\end{abstract}


Kata Kunci: Tanah, Status Hukum, Tata Ruang, dan Bencana Alam.

\begin{abstract}
The results suggest the following: 1) the community in the areas affected by liquefaction is according to the governor regulation number 10 of 2019 in which the community can no longer claim their land in areas affected. It is clearly stated within it that Petobo Sub-district belongs to the red zone which means that the people affected were relocated to a safer place and thus are not able to claim the land in the affected area; 2) the governor regulation number 10 of 2019 regulates the regional spatial planning which needs change in terms of utilizing spaces in several areas affected by massive disasters. That is why it is necessary to have arrangements for the utilization of new spaces that are acceptable to the community. On the other hand, the unaffected areas would undergo either minimal or absent change. In conclusion, the people in Petobo, Palu, Central Sulawesi, based on the governor regulation number 10 of 2019, are no longer able to claim their lands as it is considered a Red Zone which only for relocating the victims of a disaster. The provincial government of Central Sulawesi has issued the 2019 Regulation of the Governor of Central Sulawesi number 10 regarding the planning of the post-disaster rehabilitation and relocation that focus on the implementation of houses construction for the victims of liquefaction who have legal rights to lands and buildings according to the law. The principal of this construction is equal and fair between the land area and the physical house.
\end{abstract}

Keywords: land, legal status, spatial planning, and natural disaster.

\title{
PENDAHULUAN
}

Tanah menjadi salah satu sumber kehidupan yang sangat penting bagi manusia sebagai sarana untuk mencari penghidupan di berbagai bidang. Masalah tanah erat sekali hubungannya dengan kehidupan manusia. Setiap orang pasti memerlukan tanah, bahkan tidak hanya dalam kehidupannya, matipun manusia masih memerlukan tanah.

Hak atas tanah adalah hak yang memberi wewenang kepada pemegang haknya untuk menggunakan dan/atau mengambil manfaat dari tanah. Perkataan "menggunakan" mengandung pengertian bahwa hak atas tanah itu digunakan untuk kepentingan bukan hanya mendirikan bangunan, misalnya pertanian, perikanan, peternakan dan perkebunan. Atas dasar kebutuhan terhadap tanah yang semakin meningkat, maka negara memiliki hak untuk mengatur dibidang pertanahan, sehingga negara harus membuat peraturan yang dapat menunjang dan mengakomodir permasalahan- 
permasalahan mengenai bidang pertanahan, sehingga rakyat mendapatkan perlakuan yang lebih adil mengenai permasalahan di bidang pertanahan.

Bencana ini menimbulkan komplikasi permasalahan dalam hal penataan dan penemuan kembali identitas tanah hak milik, karena hancurnya batas-batas tanah, dan hilangnya bukti-bukti atas kepemilikan tanah akibat bencana likuifaksi. Surat-surat kepemilikan yang dimiliki oleh masyarakat turut hilang karena ikut terendam tanah pada saat bencana itu terjadi.

Keberadaan mengenai tanah dan hak-hak yang melekat di atas tanah di indonesia, diatur dalam undang-undang nomor 5 tahun 1960 Tentang Peraturan Dasar Pokok-pokok Agraria. Undang-undang Pokok Agraria mengatur mengenai definisi tanah, yang dapat disimpulkan sebagai permukaan bumi yang dalam penggunaannya meliputi sebagian tubuh bumi yang ada dibawahnya dan sebagian ruang yang ada di atasnya dengan pembatasan sekedar diperlukan untuk kepentingan yang langsung berhubungan dengan penggunaan tanah yang bersangkutan dalam batas menurut Undang-undang Pokok Agraria. ${ }^{1}$

Menghadapi kasus-kasus konkret, diperlukan penataan tanah kembali yang memungkinkan bagi para pemegang hak atas tanah untuk dengan mudah membuktikan hak atas tanah yang dikuasai, dan juga kebijakan pemerintah untuk memberikan kepastian hukum hak atas tanah pasca bencana alam likuifaksi di kota palu. Undang-undang Dasar Republik Indonesia Amandemen ke IV Tahun 1945 telah memberikan landasan yakni dalam pasal 33 ayat (3) yang berbunyi "Bumi, air dan kekayaan alam yang terkandung didalamnya dikuasai oleh negara dan dipergunakan untuk sebesar-besar kemakmuran rakyat".

Ketentuan pendaftaran tanah di indonesia diatur dalam pasal 19 Undang-undang Pokok Agraria yang memerintahkan diselenggarakaannya pendaftaran tanah dalam rangka jaminan kepastian hukum dan perlindungan hukum kepada pemegang hak atas tanah, dengan alat bukti yang dihasilkan pada akhir proses pendaftaran tersebut berupa buku tanah dan sertifikat tanah yang terdiri dari salinan buku tanah dan surat ukur. ${ }^{2}$

Ada 2 (dua) keadaan yang akan menimbulkan permasalahan dan penyelesaiaan terhadap hak milik atas tanah. Pertama, jaminan kepastian atau pun perlindungan yang efektif terhadap hak kepemilikan atas tanah. Kedua, prinsip pendaftaran tanah dan atau pun peraturan perundangundangan lainnya secara langsung atau tidak langsung akan mempengaruhi

1 A P Parlindungan, Komentar Atas Undang-Undang Pokok Agraria, Alumni, Bandung, 1990, hlm. 25

2 Adrian Sutedi, Peralihan Hak Atas Tanah dan Pendaftarannya, Sinar Grafika, Jakarta, 2007,hlm.12 
pejabat atau pegawai pertanahan, melakukan perlindungan hak kepemilikan atas tanah, yang bersangkut paut dengan registrasi dan ajudikasi pemberian kepastian hukum kepada individu atas pemilikan tanah korban bencana alam likuifaksi.

Berkenan dengan hal tersebut maka tujuan dari peneltian ini adalah Mengetahui dan menganalisis terhadap status hak atas tanah masyarakat pasca bencana akibat likuifaki di kelurahan petobo, kota palu dan Mengetahui dan menganalisis rencana tata ruang wilayah pada perkembangan kawasan pemukiman pasca likuifaksi di kota palu.

\section{METODE PENELITIAN}

Penelitian ini termasuk penelitian yuridis empiris. Metode pendekatan yang digunakan adalah yuridis sosiologis. Dalam penelitian ini digunakan pendekatan mengidentifikasi data yang didapat secara langsung melalui penelitian lapangan dengan melihat sesuatu berdasarkan kenyataan hukum didalam masyarakat, melihat aspek-aspek hukum dalam interaksi sosial didalam masyarakat yang berfungsi sebagai sumber utama untuk mengidentifikasi dan mengklarifikasi temuan bahan non hukum bagi keperluan penelitian atau penulisan hukum. Sumber data ini terdiri atas data primer, data sekunder, dan data tersier teknik pengumpulan bahan hukum di pergunaka dalam penelitian ini adalah penelitian lapangan (Field Research), kemudian analisis bahan hukum dilakukan secara kualitatif.

\section{PEMBAHASAN}

\section{A. Status Hak Atas Tanah Masyarakat Pasca Bencana Akibat Likuifaksi Di Kelurahan Petobo, Kota Palu.}

\section{Profil Kecamatan Palu Selatan, Kelurahan Petobo, Kota Palu}

Berdasarkan Peraturan daerah kota palu Nomor 16 Tahun 2011 Tentang Rencana Tata Ruang Wilayah Kota Palu Tahun 2010-2030, Kelurahan Petobo diperuntukan sebagai kawasan perumahan kepadatan rendah, sebagaimana yang diatur pada pasal 45 ayat (2) huruf $C .{ }^{3}$ Profil Kecamatan Palu Selatan Kemudian diterbitkan dan disahkan dengan terbitnya Undang-Undang Nomor 4 Tahun 1994 mengenai pembentukan Kecamatan Palu Selatan pada tanggal 13 Oktober 1994 sehingga wilayah Kecamatan Palu Selatan yang sebelumnya dari 12 kelurahan menjadi 5 kelurahan, terdiri dari wilayah Kecamatan-kecamatan sebagai berikut :

a. Kecamatan Palu Barat,

b. Kecamatan Palu Timur,

${ }^{3}$ Peraturan Daerah Kota Palu No. 16 Tahun 2011 tentang Rencana Tata Ruang Wilayah Kota Palu Tahun 2010-2030. 
c. Kecamatan Palu Selatan,

d. Kecamatan Palu Utara.

\section{Zona Ruang Rawan Bencana Kota Palu Dan Sekitarnya}

Pemerintah daerah kota palu menetapkan zona ruang rawan bencana yang di atur dalam Peraturan Gubernur Sulawesi Tengah Nomor 10 Tahun 2019 Tentang Rencana Rehabilitasi Dan Rekonstruksi Pascabencana.Penetapan zona merah juga mengakibatkan masyarakat yang memiliki tanah di daerah tersebut dilarang untuk membangun kembali permukiman di wilayah tersebut.

Dengan adanya penetapan zona merah, maka tentunya akan menghilangkan hak atas tanah pada pemiliknya. Pemerintah kota palu dalam hal ini akan mempertegas penetapan kawasan zona merah tersebut akan menuangkannya dalam RTRW (Rencana Tata Ruang Wilayah) dan RDTR (Rencana Detail Tata Ruang). ${ }^{4}$ Atas dasar ketentuan pasal 4 ayat (2) Undang-undang Pokok Agraria (UUPA), kepada pemegang hak atas tanah diberi wewenang untuk menggunakan tanah yang bersangkutan, demikian pula tubuh bumi dan air serta ruang yang di atasnya sekedar diperlukan untuk kepentingan langsung yang berhubungan dengan penggunaan tanah, ${ }^{5}$ walau di sadari dalam hal ini ada batas-batas menurut UUPA dan peraturanperaturan hukum lain yang lebih tinggi.

Dalam menangani hal tersebut pemerintah mempersiapkan kawasan khusus bagi masyarakat yang tempat tinggalnya rusak berat ataupun kawasannya berada pada zona merah. Masyarakat tersebut rencananya di relokasi ke lahan baru sebagai ganti atas tanah yang berada di zona merah berupa hunian yang disebut sebagai hunian tetap (huntap), akan tetapi tanah hak milik yang sebelumnya masuk dalam zona merah tidak dapat lagi sepenuhnya menjadi haknya karena tidak dapat memanfaatkan tanah tersebut akibat larangan membangun di atas kawasan zona merah yang di tetapkan oleh pemerintah.

Hunian tetap diperuntukan bagi korban bencana yang sudah tidak mempunyai tempat tinggal lagi dan juga bagi mereka yang tempat tinggalnya masuk dalam kawasan rawan bencana yang dilarang ditinggali menurut aturan pemerintah. Kelancaran proses pembangunan hunian tetap (huntap) tentunya membutuhkan peran dari berbagai pihak. Pihak yang terlibat dalam penanganan tersebut yakni Pemerintah Daerah Kota Palu yang dibantu oleh instansi-instansi pemerintahan yang terkait seperti Badan

${ }^{4}$ http://www.merdeka.com/uang/pemerintah-tetapkan-zona-merah-di-palu.html. Diakses pada tanggal 14-oktober-2020 pukul $10.47 \mathrm{wib}$

${ }^{5}$ Urip Santoso, Hukum Agraria Kajian Komperhensif, kencana Prenada Media Group, Jakarta, 2012, hal,10. 
Penanggulangan Bencana Daerah, Badan Pertanahan Nasional ,dan Dinas Penataan Ruang dan Pertanahan Kota Palu.

Akan tetapi harus disadari bahwa sisi lain dari tanah yang perlu diperhitungkan adalah aspek yuridis. Mengingat pada kenyataannya banyak permasalahan tanah yang muncul dan dialami oleh masyarakat. Oleh karena itu sisi yuridis atas tanah harus menjadi pertimbangan serius karena menyangkut kepastian hukum bagi pihak yang memanfaatkan tanah tersebut untuk saat ini dan jangka waktu kedepannya. Tanah dari sisi yuridis berkaitan erat terhadap hak atas tanah. Sebagai hak dasar, hak atas tanah sangat berarti sebagai tanda eksistensi, kebebasan dan harkat diri seseorang. ${ }^{6}$

Sehingga pemerintah dalam hal pelaksanaan pembangunan hunian tetap harus memastikan bahwa tanah yang digunakan sebagai lokasi pembangunan hunian tetap bagi korban bencana alam adalah legal. Pembangunan hunian tetap sejatinya dapat juga dikonsepsikan sebagai bagian dari kepentingan umum karena merupakan bagian dari kepentingan masyarakat. Hal tersebut ditegaskan dalam pasal 1 ayat (6) Undang-undang No.2 Tahun 2012 tentang Pengadaan Tanah Bagi Pembangunan Untuk Kepentingan Umum yang berbunyi: "kepentingan umum adalah kepentingan bangsa, negara dan masyarakat yang harus diwujudkan oleh pemerintah dan digunakan sebesar-besarnya untuk kemakmuran rakyat".

\section{Tanggungjawab Pemerintah Terhadap Masyarakat di Kawasan Terdampak Bencana Likuifaksi (Kelurahan Petobo, Kecamatan Palu Selatan, Kota Palu, Provinsi Sulawesi Tengah)}

Pada dasarnya pembangunan huntap tidak terlepas dari alasan kebencanaan. Sehingga Undang-undang No. 24 Tahun 2007 Tentang Penanggulangan Bencana menjadi acuan dalam pelaksanaan relokasi dan rekonstruksi bagi korban bencana alam. Hal tersebut berkesinambungan dengan hasil wawancara di kantor BPBD Kota Palu, bahwa "untuk Provinsi Sulawesi Tengah saat ini pelaksanaannya secara umum mengacu pada undang-undang kebencanaan yaitu UU 24/2007."7 Dalam Undang-undang tersebut dikatakan bahwa penanggulangan bencana berlandaskan Pancasila dan Undang-Undang Dasar Republik Indonesia Tahun 1945. Adapun peran pemerintah dan pemerintah daerah dijelaskan pada pasal 5 dan pasal 6 Undang-undang No. 24 Tahun 2007 yakni pasal 5 berbunyi "Pemerintah dan Pemerintah daerah menjadi penanggung jawab dalam

${ }^{6}$ Budi Harsono, Hukum Agraria Indonesia, sejarah pembentukan undang-undang pokok agraria, isi dan pelaksanaannya (Djambatan:Jakarta,2003),hal.24

${ }_{7}$ Wawancara penulis dengan Bapak Irsan sidjo ,BPBD Kota Palu, pada tanggal 3 juli 2020 
penyelenggaraan penanggulangan bencana" dan pasal 6 berbunyi "Tanggungjawab pemerintah dalam penyelenggaraan penanggulangan bencana meliputi, diantaranya":

a. Pengurangan resiko bencana dan pemaduan pengurangan risiko bencana dangan program pembangunan;

b. Perlindungan masyarakat dari dampak bencana;

c. Penjaminan pemenuhan hak masyarakat dan pengungsi yang terkena bencana secara adil dan sesuai dengan standar pelayanan minimum;dsb.

Terkait huntap dapat dikatakan bagian dari program rehabilitasi dan rekonstruksi pascabencana, sehingga dapat menyelenggarakannya pada hakekatnya dapat dilakukan di atas tanah yang berasal dari tanah negara atau tanah yang dikuasai langsung oleh negara.pembangunan huntap tersebut di dasari atas fenomena bencana alam di mana bencana dalam pengertian hukum adalah peristiwa atau rangkaian peristiwa yang mengancam dan mengganggu kehidupan dan penghidupan masyarakat.

\section{Status Hak Atas Tanah Masyarakat Di Kawasan Terdampak Bencana Likuifaksi (Kelurahan Petobo, Kecamatan Palu Selatan, Kota Palu, Provinsi Sulawesi Tengah)}

Bencana alam gempa dan likuifaksi yang terjadi di Palu, Sigi dan Donggala telah meluluhlantakkan bangunan maupun harta benda milik penduduk. Bahkan, di daerah seperti palu dan sekitarnya, bangunan instansi pemerintahan nyaris rata dengan tanah dan menghancurkan dokumendokumen penting. Korban yang saat ini selamat dari bencana alam tersebut, umumnya telah kehilangan rumah sebagai bangunan tempat tinggal. Mereka yang menjadi korban sekeluarga harus meninggalkan aset dan harta benda.

Dalam surat yang ditujukan kepada Menteri Agraria dan Tata Ruang/Kepala Badan Pertanahan nasional tersebut juga Kepala Kantor Wilayah Badan Pertanahan Nasional bahwa pada bulan februari tahun 2020 telah dikeluarkan surat pemberitahuan yang ditujukan kepada Kepala Kantor Pertanahan Kota palu, Kepala Kantor Pertanahan Kabupaten Sigi dan Kepala Kantor pertanahan Kabupaten Donggala, agar bidang tanah yang masuk dalam kategori-3 (Bidang Tanah masuk dalam zona likuifaksi) objek tanah dimaksud, untuk sementara tidak diterbitkan hak atas tanah (status quo) sampai ada petunjuk khusus atau surat edaran dari Kementerian Agraria dan Tata Ruang Kepala Badan Pertanahan Nasional. ${ }^{8}$

Dalam hal ini, pemilik tanah tidak dapat mengupayakan atau mengurus kembali batas-batasnya, karena tanah tersebut sudah tidak layak

${ }^{8}$ Wawancara penulis dengan Kepala Badan Pertahan Nasional provinsi Sulawesi Tengah pada tanggal 05 bulan juni 2020 
untuk di jadikan permukiman atau tempat tinggal. Pemerintah kota palu bertanggungjawab dalam merelokasi warganya yang terkena dampak bencana alam likuifaksi ke tempat yang lebih aman untuk mendapatkan fasilitas tempat tinggal/hunian tetap bagi korban bencana alam Gempa bumi, Tsunami dan Likuifaksi. Pemerintah Daerah Kota Palu dalam hal ini diwakili oleh Badan Pertanahan Nasional (BPN) memberikan Status hak atas tanah menjadi Status Hak Milik bagi korban bencana likuifaksi yang telah di relokasi di tempat relokasi hunian tetap. Sebagaimana ditegaskan didalam Pergub Nomor 10 Tahun 2019 tentang Rencana Rehabilitasi dan Rekonstruksi pasca bencana pada BAB V, angka 5.3.3 Zona Likuifaksi masif pasca gempa (Seperti kawasan Petobo, Balaroa, Jono Oge Lolu dan Sibalaya), sesuai ketentuan pemanfaatan ruang pasca bencana, antara lain:

1) Dilarang pembangunan kembali dan pembangunan baru, unit hunian pada zona ini direkomensikan untuk direlokasi;

2) Diprioritaskan pemanfaatan ruang untuk fungsi kawasan lindung, Ruang Terbuka Hijau (RTH) dan monument.

Dengan demikian, dapat ditarik kesimpulan bahwa masyarakat di kawasan terdampak (Kelurahan Petobo, Kecamatan Palu Selatan, Kota Palu, Provinsi Sulawesi Tengah) sesuai dengan Pergub Nomor 10 Tahun 2019, bahwa masyarkat tidak dapat lagi menuntut tanahnya di kawasan terdampak. Sebab, sangat jelas didalam pergub Nomor 10 Tahun 2019 bahwa kawasan terdampak (Keluarahan Petobo) termasuk dalam Zona Merah, yang dalam hal ini dengan dipindahkannya masyarakat korban bencana dikawasan terdampak ke lokasi yang lebih aman (relokasi). Maka, dengan adanya relokasi tersebut, masyarakat tidak lagi dapat menuntut hak atas tanahnya dikawasan terdampak.

\section{B. Penetapan Rencana Tata Ruang Wilayah Pada Perkembangan Kawasan Permukiman Pasca Likuifaksi Di Kota Palu. \\ 1. Tinjauan Umum Perencanaan dan Penataan Ruang}

Penyusunan rencana tata ruang berbasis mitigasi bencana perlu diutamakan terhadap peristiwa likuifaksi yang terjadi di kota palu. Banyak permasalahan yang timbul pada saat menyusun rencana ini, terutama setelah bencana akibat berubahnya topografi, kondisi sosial ekonomi masyarakat. Sesuai Undang-undang nomor 26 tahun 2007 tentang Penataan Ruang, kabupaten dan kota diberikan kewenangan dalam menyusun rencana tata ruang secara komprehensif dengan memanfaatkan ruang dan melakukan pengawasan dan pengendalian kegiatan di dalam ruang.

Kawasan kelurahan petobo, kecamatan palu selatan, kota palu yang secara administrasi merupakan bagian dari kecamatan palu selatan adalah merupakan kawasan paling parah terkena dampak bencana likuifaksi yang 
ditandai dengan hancurnya perumahan dan permukiman, fasilitas sosial ekonomi, serta jaringan jalan dan juga banyak memakan korban jiwa. Sesuai dengan strategi pengembangan kota palu, Rencana Tata Ruang Wilayah terbangunnya kawasan permukiman baru pasca likuifaksi ke daerah lebih aman, yaitu kawasan Huntap (hunian tetap) Tondo 1, kawasan huntap tondo 2, kawasan huntap talise, dan kawasan huntap duyu.

Gempa bumi yang diikuti likuifaksi pada tanggal 28 September Tahun 2018 telah merusak kawasan perumahan permukiman kelurahan petobo di wilayah kota palu, Provinsi Sulawesi Tengah dengan korban lebih dari 2.101 jiwa meninggal dunia, 4.438 jiwa luka berat dirawat inap dan 83.122 jiwa luka ringan dirawat jalan, total yang terdampak bencana sebanyak 89.661 jiwa. Walaupun kota palu telah memiliki RTRW yang tertuang dalam Perda Nomor 16 Tahun 2011 tentang Rencana Tata Ruang Wilayah (RTRW) Kota Palu, namun wilayah yang terkena dampak bencana ini harus di rencanakan dan di tata kembali mengikuti kaidah-kaidah dan norma-norma perencanaan yang tepat dan memasuki aspek mitigasi terhadap bencana alam, dalam rangka meminimalkan resiko di kemudian hari, dengan memberikan kesempatan masyarakat untuk berpartisipasi dalam proses perencanaan dan implementasinya.

\section{Faktor-Faktor Yang Dipertimbangkan Dalam Pelaksanaan Relokasi Permukiman Dan Perlindungan Hukum Hak-Hak Masyarakat}

Hal-hal yang menjadi faktor-faktor yang dapat dipertimbangkan dalam pelaksanaan relokasi ada beberapa yang harus diperhatikan, yaitu:

a) Perlunya Koordinasi Sejak Tahap Perencanaan, Pelaksanaan, Sampai Dengan Evaluasi

b) Pemilihan Areal Relokasi Lokasi Dan Kualitas Tempat

c) Hak Masyarakat yang akan dipindahkan

d) Kelengkapan Fisik Lokasi Permukiman Kembali

e) Bentuk Rumah Dan Bangunan Yang Relevan

f) Status Hak Atas Tanah

g) Dukungan Terhadap Pemulihan Tingkat Kehidupan Masyarakat

Pada tanggal 03 juli tahun 2020 penulis melakukan wawancara dengan bapak Tarug Azir selaku bagian perencanaan penataan ruang wilayah kota palu. Bahwa kawasan terdampak bencana (likuifaksi) di kelurahan petobo, kecamatan palu selatan, kota palu tidak bisa diperuntukkan atau dibangunkan perumahan atau dengan kata lain tidak bisa dijadikan kembali sebagaimana mestinya lokasi pemukiman seperti halnya dahulu, dikarenakan kawasan tersebut berpotensi untuk terjadi likuifaksi. Dalam kaitannya dengan hal itu, kawasan-kawasan terdampak bencana 
(likuifaksi) termasuk kawasan kelurahan petobo, kecamatan palu selatan, kota palu rencananya akan dimanfaatkan sebagai area Ruang Terbuka Hijau (RTH) namun rencana masih belum disahkan dalam satu bentuk peraturan perundang-undangan, yang ada hanyalah baru sebatas rancangan Perda Kota Palu tentang Rencana Tata Ruang Wilayah Kota Palu, dan rancangan tersebut belum diajukan dan disusulkan untuk dibahas Pemerintah Kota palu bersama Anggota Dewan Perwakilan Rakyat Kota Palu.

Berdasarkan penjelasan penulis diatas tentang pentingnya kepastian hukum dan perlindungan hukum hak masyarakat, maka jelas bahwa dengan terjadinya bencana alam (likuifaksi) di Provinsi Sulawesi Tengah khususnya Kota Palu, kelurahan petobo, kecamatan palu selatan. Maka, penulis memandang bahwa pemerintah Kota Palu lambat dalam penanganan penataan ruang di Kota Palu dan juga penulis memandang perlu untuk kiranya dilakukan revisi Peraturan Daerah Kota Palu Nomor 16 Tahun 2011 Tentang Rencana Tata Ruang Wilayah Kota Palu.

\section{Penetapan Rencana Tata Ruang Wilayah Pada Perkembangan Kawasan Permukiman Pasca Likuifaksi Di Kota Palu}

Berdasarkan Peraturan Gubernur Sulawesi Tengah nomor 10 Tahun 2019 tentang Rencana Rehabilitasi dan Rekonstruksi Pascabencana, mengatur mengenai Penataan Ruang Wilayah Dan Kawasan Rawan Bencana yaitu mengenai struktur dan pola ruang wilayah terdampak bencana dikembalikan fungsinya, bila memungkinkan, atau dijadikan fungsi lindung, apabila bila tidak memungkinkan untuk digunakan kembali, pendekatan pemulihan ini berbasis pada pendekatan mitigasi dan adaptasi bencana dimasa yang akan datang. ${ }^{9}$

Mengingat bencana yang terjadi di Provinsi Sulawesi Tengah mengindikasikan perlunya perubahan pemanfaatan ruang di beberapa lokasi terdampak bencana masif, maka menjadi penting penyusunan arahan pemanfaatan ruang baru yang dapat diterima oleh masyarakat. Disamping itu, di daerah-daerah yang tidak terdampak bencana, maka arahan pemanfaatan ruang lama akan mengalami perubahan minimal, atau bahkan tidak berubah sama sekali.

Sebagai salah satu Provinsi dengan potensi bencana yang beragam, pengendalian pemanfaatan ruang di Provinsi Sulawesi Tengah sangat penting. Pemanfataan ruang yang berlandaskan informasi Kajian Resiko Bencana (KRB) menjadi sebuah keharusan. Disamping itu, penegakan rencana tata ruang melalui arahan pengendalian pemanfaatan ruang diharapkan dapat mencegah timbulnya korban jiwa yang banyak bila terjadi bencana dimasa yang akan datang.

9 Pergub Nomor 10 Tahun 2019 Tentang Rencana Rehabilitasi dan Rencana Rekonstruksi Pascabencana 
Pasca kejadian bencana, pembinaan kelembagaan penataan ruang daerah perlu dilakukan. Ini bukan hanya pengendalian fungsi-fungsi pemerintahan daerah dalam urusan penataan ruang, tetapi juga memastikan instrumen kelembagaan penataan ruang daerah mempertimbangkan risiko bencana di dalam perencanaan, pemanfaatan dan pengendalian pemanfaatan ruang ke depannya.

Sebagaimana yang telah diuraikan di atas bahwa bencana di Provinsi Sulawesi Tengah menyebabkan kerusakan di sebagian wilayah Kota Palu, Kabupaten Donggala, Kabupaten Sigi, dan Kabupaten Parigi Moutong. Kerusakan yang terjadi antara lain kerusakan permukiman, infrastruktur (jalan, jembatan, dsb) dan berbagai fasilitas pendukung lainnya. Kerusakan yang terjadi mengindikasikan adanya perubahan pola dan struktur ruang di empat (4) kabupaten yang terdampak. Oleh sebab itu, diperlukan peninjauan kembali Rencana Tata Ruang Wilayah (RTRW) Provinsi Sulawesi Tengah serta RTRW Kabupaten/Kota yang terdampak.

Berdasarkan Pasal 82 PP 15 Tahun 2010 tentang Penyelenggaraan Penataan Ruang, peninjauan kembali rencana tata ruang dapat dilakukan: (i) hanya 1 kali dalam 5 tahun; atau (ii) lebih dari 1 kali dalam 5 tahun bila terjadi perubahan lingkungan strategis dikarenakan bencana skala besar, perubahan batas teritorial negara, atau perubahan batas wilayah daerah. Status perda RTRW Provinsi Sulawesi Tengah dan Perda RTRW Kabupaten dan Kota yang terdampak saat ini telah memasuki peninjauaan kembali, sehingga upaya perbaikan RTRW di daerah tersebut telah sesuai dengan peraturan perundang-undangan yang berlaku.

Selain kegiatan peninjauan kembali Rencana Tata Ruang Wilayah Provinsi/Kabupaten/kota, dibutuhkan juga penyusunan Peraturan daerah Rencana Detail Tata Ruang. Peraturan Daerah tersebut akan menjadi instrumen operasional Rencana Tata Ruang Wilayah Kabupaten/Kota dalam skala yang lebih besar yaitu skala 1:5000 dan menjadi dasar dalam pemberian izin lokasi pemanfaatan ruang. Peraturan zonasi yang juga diatur dalam peraturan daerah Rencana Detail Tata Ruang menjadi sangat penting untuk membantu pemerintah daerah dalam mengendalikan pemanfaatan ruang (pembangunan). Peraturan daerah Rencana Detail Tata Ruang juga dapat berfungsi sebagai penghubung rencana tata ruang dengan ketentuan tata bangunan.

Regulasi yang akan digunakan sebagai dasar penyusunan RTRW dan RDTR meliputi UU 26/2007 tentang Penataan Ruang dan PP 15/2010 tentang Penyelenggaraan Penataan Ruang. Penyusunan RTRW akan berpedoman pada Permen ATR 16/2018 tentang Pedoman Penyusunan Rencana Detail Tata Ruang dan Peraturan Zonasi Kabupaten/Kota. 


\section{KESIMPULAN}

Bahwa masyarakat di kawasan terdampak (Kelurahan Petobo, Kecamatan Palu Selatan, Kota Palu, Provinsi Sulawesi Tengah) sesuai dengan Pergub Nomor 10 Tahun 2019, bahwa masyarkat tidak dapat lagi menuntut tanahnya di kawasan terdampak. Sebab, sangat jelas didalam pergub Nomor 10 Tahun 2019 bahwa kawasan terdampak (Keluarahan Petobo) termasuk dalam Zona Merah, yang dalam hal ini dengan dipindahkannya masyarakat korban bencana dikawasan terdampak ke lokasi yang lebih aman (relokasi). Maka, dengan adanya relokasi tersebut, masyarakat tidak lagi dapat menuntut hak atas tanahnya dikawasan terdampak.

Pemerintah Daerah Provinsi Sulawesi Tengah telah mengeluarkan Peraturan Gubernur Sulawesi Tengah No. 10 Tahun 2019 Tentang Rencana Rehabilitasi dan Relokasi Pascabencana, yang mengatur pelaksanaan pembangunan rumah untuk relokasi korban likuifaksi yang memiliki hak atas tanah dan bangunan secara sah menurut hukum. pembanguan tempat tinggal untuk relokasi disini prinsipnya adalah pemerataan dan adil antara luas tanah dan fisik rumah adalah sama.

Berdasarkan kesimpulan yang telah diuraikan di atas, maka penulis menulis saran dengan ditetapkannya kawasan terdampak (petobo) termasuk dalam zona merah dalam ZRB tersebut sebagaimana terdapat didalam Pergub Nomor 10 Tahun 2019 Tentang Rencana Rehabilitasi dan Rekonstruksi pasca bencana. Maka sekiranya pemeritah Kota Palu perlu mensosialisasikan isi Pergub tersebut yang artinya bahwa dengan dipindahkannya masyarakat terdampak bencana ke tempat yang lebih aman (Relokasi) tersebut maka masyarakat tidak dapat lagi menuntut tanahnya di kawasan yang terdampak bencana alam (likuifaksi).

Upaya pemerintah untuk tetap bersinergi atas keprihatinan kepada masyarakat yang terdampak korban bencana gempa bumi, tsunami dan likuifaksi di kota palu. Jadi, Perlunya peninjauan kembali terhadap rencana tata ruang wilayah kabupaten/kota dan selanjutnya melakukan revisi rencana tata ruang wilayah berdasarkan tingkat ancaman bencana per wilayah.

\section{DAFTAR PUSTAKA}

A P Parlindungan, Komentar Atas Undang-Undang Pokok Agraria, Alumni, Bandung, 1990

Adrian Sutedi, Peralihan Hak Atas Tanah dan Pendaftarannya, Sinar Grafika, Jakarta, 2007

Budi Harsono, 2003, Hukum Agraria Indonesia, Sejarah Pembentukan Undang-Undang Pokok Agraria, Isi Dan Pelaksanaannya, Djambatan, Jakarta. 
Urip Santoso, 2012, Hukum Agraria Kajian Komperhensif, kencana Prenada Media Group, Jakarta.

Peraturan Daerah Kota Palu No. 16 Tahun 2011 tentang Rencana Tata Ruang Wilayah Kota Palu Tahun 2010-2030.

Peraturan Gubernur Nomor 10 Tahun 2019 Tentang Rencana Rehabilitasi dan Rencana Rekonstruksi Pascabencana

Wawancara penulis dengan Kepala Badan Pertahan Nasional provinsi Sulawesi Tengah pada tanggal 5 juni 2020.

Wawancara penulis dengan Bapak Irsan sidjo (BPBD Kota Palu), pada tanggal 3 juli 2020.

http://www.merdeka.com/uang/pemerintah-tetapkan-zona-merah-dipalu.html. Diakses pada tanggal 14-oktober-2020 pukul 10.47 wib. 